\title{
Dromokratik Çağda Eğitim ve Okulun Açmazları: Paul Virilioik Açıdan Analojik Bir Çözümleme ${ }^{1}$
}

\author{
DOI: $10.26466 /$ opus.724349
}

\begin{abstract}
Hamit Özen * *
** Doç. Dr. , Eskişehir Osmangazi Universitesi, Eğitim Fakültesi E-Posta: $\underline{\text { hamitozen@hotmail.com }}$

ORCID: 0000-0001-7604-5967

Öz

Bu çalışma, Paul Virilio'nun hız ve politikaya dair düşünceleri doğrultusunda eğitim ve okul kavramların irdelemeyi amaçlayan analojik bir çözümlemedir. Günümüzde eğitim ve okul öğrencilerini zihin ve bedenlerine yönelik teknolojik-prosedürel donatılarla haz ve hız bağımlısı yapmaktadır. Böylece zihinlerini kitlesel olarak işleyerek bir egemen kitle ile üzerinde egemen olunan standart kitleler yaratmaktadır. Bu bilimin adı dromolojidir. Dromoloji eğitim aracılığıyla dromokratik bir sistemin kendi eğitim sistemini yaratmaktadır. Dromokratik okul ve eğitim öğrencilerini sinavlar aractlı̆̆ılla hiyerarşik bir şekilde sıraya dizmekte, seçmekte, sinıflandırmaktadır. Bu seçim aracılığıyla sosyo-ekonomik düzeyi düşük aile çocukları düşük nitelikli okullara, elit aile çocuklarn ise nitelikli okullara gönderilmektedir. Oluşturulan piyasacı düzenin elit öğrencileri kapitalist egemen sınıfı oluştururken, seçilemeyenleri ise toplumsal atık olarak görülmektedir. Sonuç olarak modern okul ve eğitim düzenlerindeki bu tür pratikler, okulun sosyal hayatın zayıflatmakta ve yok etmektedir. Okullar, öğrenciyi çağdaş uygarlık hedefine yürümesine katkı verme yerine piyasacl, teknisist ve konformist yaşamı yeniden üreten ve geliştiren mekânlara dönüşmektedir. Çağcll dünyada dromolojik okul, dromokratik eğitimin haz ve hız arasındaki fraktal, speküler ve paradoksal epistemolojisi insan ruhunu teknik makinaya dönüştürmeye devam etmekte böylece modern okul amaçlarna uygun işlevlerini yerine getirmeyi sürdürmektedir.
\end{abstract}

Anahtar Kelimeler: Paul Virilio, hız ve politika, eğitim politikaları, modern okul

\footnotetext{
${ }^{1}$ Bu çalışmanın bir bölümü Felsefe, Eğitim ve Bilim Tarihi Sempozyumu'nda sözlü bildiri olarak sunulmuştur
} 


\title{
Dilemmas of Education and Schools in Dromocratic Societies: A Paul Viriloic Analogical Analysis
}

\begin{abstract}
This study is an analogical analysis aimed at examining the concepts of education and school in line with Paul Virilio's thoughts on speed and politics. Today, education and school make their students addicted to pleasure and speed embedding technological-procedural equipment their mind and body. They create dominant classes dominating standart masses processing their minds. The name of this science is dromology. Dromology creates a dromocratic system's creating its own system through education. Thus, the dromocratic school and education students are hierarchically ordered, selected and classified through exams. Through this selection, family children with low socio-economic level are sent to low-quality schools, and elite family children to qualified schools. While the elite students of the market constitute the capitalist ruling class, those who cannot be elected are seen as social waste. Consequently, such practices in a modern school and educational settings weaken and destroy the social life of the school. Instead of contributing the students'to the goal of contemporary civilization, schools are transformed into places that reproduce and develop marketer, technician, and conformist life. In today's world, dromological school continues to transform the human soul into technical machinery, fractal, specular and paradoxical epistemology of dromocratic education between pleasure.
\end{abstract}

Keywords: Paul Virilio, speed and politics, education policies, modern school 


\section{Giriş}

Gelişmiş toplumlar eğitim aracılığı ile değişim ve dönüşüme daha hızlı adapte olarak diğer toplumlara her alanda üstünlük kurmaktadırlar. Çünkü belirsizliklerin kesinlikleri reddederek her alanda sınırsız gelişimlerin yaşandığı bir dünyada, eğitim insanların karşılaştığı olguları ontolojik, epistemolojik ve metodolojik açıdan nasıl değerlendirmesi gerektiğini gösteren bir belirleyicidir.

Geleceği şekillendirecek olan en önemli özelliklerden biri insanın sahip olacağı entelektüel bilgi ve becerileridir. Bu nitelikler de en iyi şekilde eğitim ve eğitim kavramı üzerinde olgusallaştırılan okul gibi sosyolojik kurumlar aracılığıyla gelecek nesillere kazandırılmaktadır (Aypay, Sever ve Demirhan, 2012) . Okullar öğrencilerin (okul denen bağlamda) fiziksel, ruhsal ve entelektüel gelişiminin sağlanmasına aracılık eden karmaşık organizasyonlardır (Boyd 1992, s. 9). Buna ilave olarak eğitim aracılığıyla okullar, hem toplum kültürünü çocuklara ve gençlere öğretmek, benimsetmek hem de fertleri ilgi ve yeteneklerine göre belli görevlere yerleştirmekle görevlidirler (Ergün, 2015).

Modern zamanların üretmiş olduğu en önemli kültürel ve politik aygıtlardan biri olan okul; demokratik bir toplum, daha adil, daha humanist bir dünya inşası gibi temel amacından uzaklaşmakta, bireyler üzerinde egemenlik kurma ve kontrol mekanizması oluşturma aracına dönüş(türül)mektedir (Geuss, 1981; Liston, 1988, Wink, 2004). Bir başka ifade ile okul, modern dünyanın yüzyüze kalmış olduğu toplumsal, psikolojik ve sosyal sorunları çözememekte, bireylerin özne olma, düşünme ve eylemde bulunma yönündeki kapasitelerini geliştirememektedir (Turan, 2014). Günümüz modern okulu çıkmazdadır, ontolojik amaçlarından sapmış ve kendi sınıfını yeniden üreten bir aygita dönüşmüştür (Bourdieu, 1973).

Genel olarak düşünürler toplumsal dönüşümleri daha iyi analiz etmek için çeşitli felsefi kuramlardan ve kavramlardan faydalanmaktadırlar. Örneğin Althusser eğitimin gizli işlevinin sermayenin ve egemen güçlerin emekgücü gereksinimini karşlamak ve yeniden üretmek olduğunu ileri sürmektedir. Burada eğitim öğrencileri yetenekleri doğrultusunda kapitalist üretimin arttırılması için sadece teknik ve prosedürel kapasitelerini yetiştirmektedir (Akın ve Arslan, 2014). 
Baudrillard (2011) ise Simülakrlar ve Simülasyon adlı eserinde toplumsal yapıyı çözümlemek amacıyla Simulasyon Teorisi kavramına değinmiştir. Bu yaklaşımla toplumda gerçekliğin olgusal ve reel olarak birbirinden ayrıştığını, yerine ise sanalın hakim olduğunu ifade etmektedir. Baudrillard'a göre simülasyon, "bir kökenden yoksun olan, gerçeğin modeller aracilığıyla türetilmesine, gerçekten ve fiili olarak var olan bir şeyi veya durumu bütün bileşenleriyle birlikte gerçekmiş ve fiilen var 'mış gibi' gösterme durumunu simgeleyen hiper-gerçeklik durumudur. Bu durumda insanlar gerçeklik yerine gerçeğin kopyası ya da sahtesi değil bizzatihi sanalı ile gerçeği buharlaştırmaktadır (Okuyan ve Taslaman, 2018). Eğitim ortamları gerçeğin kendisi değildir, hayattan kopuktur dahası sahteliği ile bir simülasyon evrenidir (Ozen, 2017).

Bir başka eğitim çözümlemesi de Freire tarafından yapılmıştır. Bu kuramsal tanımlamanın adı geleneksel sinıfların, okulların, bilgiyi aktaran ve nesne durumundaki eğitilenlerin olduğu bankacı eğitim sistemidir. Bankacı eğitimde öğrenenin bir nesneye dönüştürülmesi olgusu temel sorunun toplumda değil bireyde olduğu varsayımını yaratır. Tam da yoksulları eğitme sürecinde, bütün kabahat yoksulara yüklenir. Başarısız oldukları söylenerek suçlanırlar (Spring, 2010). Böylece sıralayıcı eğitim sistemi ile yoksullar elenir ve toplumsal atık statüsüne dönüştürülür (Spring, 2010).

Virilio (1998) ise toplum çözümlemesini Hız ve Politika adlı eserinde kentsel mekânları dönüş̧üren gücün kapitalist sistemin savaş mantığ1 ve savaş modeli kurgusuyla yapmaktadır. Virilio (1998)'e göre, modern toplumları değiştiren, dönüştüren şey ekonomik dinamikler değil; ekonomik dinamikleri yöneten politik, teknolojik, ideolojik, askeri stratejileri değiştiren hız mantığ1dir (Aykutalp, 2017).

Paul Virilio'nun ürettiği hız ve politika kavramları bağlamında alan yazınında çeşitli kurumsal ve kuramsal çözümlemeler yapılmıştır. Ülkemizde Aykutalp (2017) tarafından yapılan çalışmada modern toplumlar irdelenmiştir. Bu irdelemede günümüzde hızın ve hız üretici araçların sadece mekanın sonunu getirmediği, zaman kavramının da tekrar hızlanmış zaman olarak yeniden üretildiği ortaya konmuştur. Bu sayede modern toplumlar hipomodern olarak hızın mantığında oluşan değişimler doğrultusunda askeri, mekansal, politik ve ekonomik bir örgütlenmelerde de değişim yaşamaktadır. Bu değişim daha bir kaç onyıl önceki değerleri, sistemleri, ahlakı ve bir çok sosyolojik olguyu değiştiren bir süreçtir. 
Altun (2015) Bir Modernite Olgusu Olarak Hızın Sanatta Gösterimi adlı çalışmasında fiziksel bir kavramdan yola çıkarak uzun bir tarihsel sürece yayılan modernitenin doğurduğu hızın sanat üzerindeki etkisini incelenmiştir. Hızın sanattaki gösterimi 19. Yüzyılın sonları ile iki dünya savaşı arasındaki süreçte yani makineleşmenin hızla yaşandığı bir dönemde yoğunluk kazandığı görülmektedir. Böylece hız, insan yaşamında ve sanatsal eserlerde yapıtın üretilmesinde, tüketilmesinde ve alımlanmasında dipten giden önemli bir akım olarak görülmektedir.

Harvey (1999) Postmodernliğin Durumu adlı eserinde mekanın zaman aracılığıyla ortadan kaldırılmasında yeniliklerin payı olduğuna işaret eder ve bu durum da zaman-mekan sıkışması olarak tanımlanır. Harvey (1999)'e göre "mekan iletişim ve sosyal medya aracılığı ile küresel köye dönüşmektedir. Bu küresel köy küçüldüke, zaman ufkumuz kısaldıkça mekan-zaman sıkışması insanlar tarafından daha da şiddetli bir şekilde hissedilir. Bu da insanları farklı bir zaman rejimine yönlendirmektedir. Sosyal değişimin hızlanması, toplumsal yaşayışın kararlılığını yitirerek istikrarsız, değişken ve gelipgeçici bir hal almasına sebep olmaktadır. Bu hızlanma bireylerin gündelik yaşamını yoğunlaştırarak psikolojik, sosyal ve fiziksel boyutta ciddi sorunlara yol açmaktadır (Akt.: Mermutlu, 2018).

Dünya günümüzde COVID-19 virüsünün sebep olduğu büyük bir pandemi yaşamaktadır. Eğitim ortamlarının paydaşlarından olan öğretmenler, öğrenciler ve aileler eğitime online (çevrimiçi) sistemler aracılığı ile teknolojik cihazlar aracıllğ 1 ile sanal ortamlarda erişmektedirler. Bu eğitim yaklaşımı ile öğrenciler, öğretmenler eğitimin asıl bağlamı olan okullardan koparılmış sanal sınıflarda zaman-mekan sıkışması yaşamaktadırlar. Eğitimin temel amacı öğrenciyi sosyalleştirmek ve kültürlemek olduğu düşünülürse zaman ve mekanda sıkıştırılmış online (çevrimiçi) eğitimin ontolojik gerçekliği nasıl yok ettiği açıkça görülmektedir.

Eğitim ve bileşenleri sayesinde öğrenmeyi kurumsal beklentilerin belirli bir vizyonu içinde yeniden konumlandıran yeni söylemler ortaya çıkmaktadır. Hem özel hem de devlet okullarında deregülasyon ve paydaşların kattlımı üzerine odaklanan bu yeniden konumlandırma, belirli bir endüstriyel sürecin terminolojisini ve zihniyetini zihinlere yerleştirmektedir. Bu yeniden konumlandırma, mikro yönetim kültürü ile önemli bir değişikliklere sebep olmaktadır. Burada öğrenme ve eğitim kaçınılmaz bir süreç olarak sıvının akışı yönetimine benzetilir. Bir başka deyişle amaç insan doğasını ontolojik 
gerçekliği içinde eğitmek değil, suyun akışı gibi kolay yoldan ve en ekonomik insan yetiştirme çabaları ön plana çıkmaktadır. Beighton (2017) çalışmasında Paul Virilio'nun hızın etkileri üzerine önermelerinden yola çıkarak günümüz eğitim kurumlarının eğitimi temsil ettiği iddialarını eleştirerek, nihilizmin bu değişimin merkezinde olduğunu belirtmektedir.

$\mathrm{Bu}$ çalışmanın problem konusu; günümüzde kurgulanan pedagojik değeri düşük eğitim sistemi sayesinde kritik düşünme, yaratıcılık, esneklik, hayret ve estetik duygudan uzak, beceriklilik ve dürüstlük gibi temel insani niteliklerle donatılamayan öğrenciler ve eğitim aracılı̆̆ıyla sözü edilen bu gerçeklikleri veremeyen okul kavramıdır. Bununla birlikte öğrencilerinin tüm çıktılarını ölçemeyen, sadece bir doğru ve dört yanlıştan oluşan aşrı basitleştirilmiş seçme yanılgısıyla onları hız ve haz bağımlısı yapan eğitim sisteminin varoluşsal gerçekliğini sorgulamaktır. Bundan dolayı varoluşsal ödevinden uzaklaşan okulun yetiştirdiği insanlar ne yazık ki günümüzde bilim tarihinin ilerlemesinin öznesi değil bilakis hakikatin hızlanmasının yarattığ baş dönmesinin öznesidir. Ayrıca literatüdeki çalışmalar göz önüne alınd1ğında eğitim ve okul bağlamında insan doğasını Hiz ve Politika üzerinden analiz eden çalışmaların neredeyse yok denecek kadar az olduğu görülmektedir. Bu açıdan mevcut çalışma teknolojinin insan yaşamına kattığ $\mathrm{H}_{1 z}$ ve Politika açısından eğitimi, okulu ve paydaşları nasıl etkilediğini ortaya koymaya çalışmaktadır. Bunu yaparken Paul Viriliónun Hız ve Politika'ya yönelik kavramları yol gösterici olmaktadır.

\section{Hız ve Haz: Dromoloji ve Dromokrasinin Ayartıcı Unsurları}

Virilio (1998) modern toplum üyelerinin hız tutkunu olduğunu söyler. Nesnenin var olması için diğer bir nesneyle çatışma içinde olması gereklidir çünkü çatışmanın sebebi var olan bir sorun değil var olmak için yaratılan bir sorundur. Bu sorun bir yaşam biçimi olarak modernitenin varlığını sürdürmesi için gerekli bir araçtır. Dromoloji de bu yaşam biçimini düzenlemek için kendi mantığ 1 içinde hız kavramı ile oluşturulmuş bilimdir. Kısaca ifade etmek gerekirse hiz, ekonomik, politik, ideolojik, askeri, toplumsal ve kentsel alanları kuşatan bir mantık olarak görülmektedir.

Dromoloji çağına değin, modern toplumları dönüştüren en önemli dinamik, ekonomi bilimi ışığında yaşanan dönüşümlerdi. Oysa şimdi toplumların tekrar dizaynı, politik, askeri, mekânsal ve teknolojik değişimlerin olduğu 
yeni bir hız mantığı uyarınca yapılmaktadır (Aykutalp, 2017). Modern çağ hizı üreten teknolojik araçlar yoluyla hareketi temel alan bir toplum ortaya çıkarmıştır. Modern toplumla birlikte ortaya çıkan hız tutkusunu, zamanı ve mekânı kontrol altına alma isteğini dromoloji (hız bilim) kavramıyla tanımlanmaktadır.

İnsanlık halihazırda ego benliği ile evreni kontrol altına almak için ekonomi biliminden tıp bilimine kadar bilim dünyasının tüm determinist enstrümanlarını kullanmaktadır. Bu süreç insanlığı insani, vicdani ve psikolojik bir çöküntüye sürüklemektedir. Zaman zaman insanlık bu çöküşü tersine çevirebilmek için iyi oluş hali olarak niteleyeceğimiz anda kalabilmeyi deneyimlemeye çalışmaktadır. An'da kalmak insan ruhunda dinginliğe yol açan bir çeşit esenlik halidir. Fakat evreni yöneten küresel muktedir, zaman-mekan kavramını bozan, değerleri yok eden hız ve hazzın merkezde olduğu ve dromokrasi olarak tanımlanan hegamonik iktidar gücünü keşfetti.

Dromokratik çerçeveden bakıldığında insanlık, ego benliği ile evreni kontrol altına almak için insan ruhunda dinginliğe yol açan An'da kalmaya yol açan zaman-mekân kavramını yok etmeyi başarırken aynı zamanda hegamonik iktidar güdüsünün hazzını keşfetmiştir (Virilio, 1998). Bu güç yok ettiği ruhi dinginliğin zaman-mekân kavramını ikame edecek, insanı hız ve haz içinde yeniden üretecek sosyolojik kurumlar keşfetmeye çalışmaktadır. Bunun için insanlık gelişim gösterdiği tarihsel süreç içinde güç kavramını her yerde aramış ve dromoloji biliminin de yardımıyla dromokratik eğitim modelleri keşfetmiştir.

Bu modellerden birisi Freire tarafından tanımlanmış ve geleneksel sınıfların, okulların, bilgiyi aktaran ve nesne durumundaki eğitilenlerin olduğu bankacı eğitim sistemidir. Bankacı eğitimde öğrenenin bir nesneye dönüştürülmesi olgusu temel sorunun toplumda değil bireyde olduğu varsayımına dayanır. Başka bir deyişle bankacı eğitim, yoksullukla ilgili olarak yoksulluğun varlı̆̆ının yoksulun toplumda nasıl davranacağını bilmemesinden kaynaklandığını varsayar. Tam da yoksulları eğitme sürecinde, bütün kabahat yoksulara yüklenir. Başarısız oldukları söylenerek suçlanırlar (Spring, 2010).

Böylece bir güç gösterisinin sebebi olarak dromokratik hegemonya; yaşanan anın egemeni olarak eğitimle her an her yerde bulunmakta, meşruiyetini oluşturarak, kapitalist bağlamlar ile gerçek arayışını yok etmektedir. Oysa öğrenme zaman ve mekânı olmayan, eylemini tek bir nesneye bırakmayacak kadar insan doğasının özüne yönelik bir kavramdır. Öğrenme eyleminin 
mekânla, teknolojik cihazlarla ve hızlı bir şekilde belirli bir zaman içine sıkıştırılması eğitim, öğretmen ve öğrenci gibi kavramları birer dromokratik kavramlara indirgemiştir.

$\mathrm{Bu}$ durum dromokratik retoriğin dromolojik eğitim ve okul aracilığıyla insan zihninin ve bedeninin kurgulanmasına ve doğasına aykırı bir şekilde yeniden üretilmesine yol açmıştır. Böylece eğitim sayesinde, okullardaki öğrencileri ve toplumdaki gençleri, hayalleri doğrultusunda yürüyemeyen, mekânlara sıkıştırarak sokakları boşaltan, hegemonyanın emrinde bulunup daha sonra ona sahip olma arzusunda olan tektipleştirilmiş, etikenlenmiş insanlar olarak bulmaktayı.

Toplumsal tabakalarda genellikle eğitim örgün eğitim kurumları aracıl1ğıyla gerçekleştirilmektedir. Bu oluşturulmuş yapının temel amacı bireylerin, toplumsal hiyerarşiyi benimsemesini sağlamaktır. Öğrenciler, eğitildikleri sosyolojik kurumlar aracılığıyla kaderleri olan sosyal sınıfın ekonomik, toplumsal ve kültürel sermayesini içselleştirirler. Eğitim sistemi, sürekli olarak aileleri zorunlu eğitim tuzağına düşürür. Kurgulanmış okullarda seçkinlerin ve varsılların çocukları başarılı olurken, dışarıda kalan toplumsal atık olarak kabul edilen dezavantajlı ailelerin çocukları habitusları ile sistemi yeniden yaratırlar. Okul ortamındaki mücadelesi esnasında birey aynı zamanda eşitsizliği kabul etmeyi de öğrenir ve habitusuna ekler (Bourdieu, 1973). Ülkemiz bağlamında da eğitim toplum içinde çözülmeler yaratarak, ayrıştırarak, eleyerek, çözerek ve dönüştürerek kendi kültürel, ekonomik ve sosyal sermayelerini oluşturan dezavantajlı ya da avantajlı habituslar yaratmakdır (Atmaca, 2019).

\section{Dromolojik Çağın Modern Okul Açmazları}

Yeni bir çağa geçiş yaptığımız ancak bireyleri gelenksel yöntemlerle yetiştirdiğimiz bir gerçekliktir. Eğer içinde yaşadığımız çağı zihni süreçlerimizi etkileyen gelişmeler açısından değerlendirebilirsek, eğitimin, okulun, öğrencilerin kısacası insanlığın yolculuğunun gidiş yönünü daha iyi görebiliriz. Artık eğitim ve okul gibi kurumların fiziki gerçekliği teknolojik aygıtlar ve sanal eğitim ortamları tarafından yok edilmektedir. Dromolojik açıdan da hızın, hücumun ve hızla hareket etme arzusunun egemenliği altındadır. İnsanlığın yaşamını idame ettirme sürecinin hızlı araçlar, otobanlar, füzeler, uçaklar ve 
nükleer başlıklarla devam etmesi, insanları hep hızlı ve daha hızlı yaşam biçimine yöneltmektedir. Bu hız kendi kendini yok etmeye doğru yönelen bir hızdır ve yaşamın tek ilkesi kalmıştır. Artık durmak ölümdür. Bundan dolayı toplumlar dromolojik kavramlar üzerinden etkileşimin doğurduğu paradoksal hiçliğe dönüşümleri yaşamaktadır (Virilio, 1998).

Dromolojik evrende dromokratik eğitim kurumları aracılığgyla üretilen bilginin en önemli sorunsalı akla uygunluk ilkesine uymamasıdır. Akla uygun bilgi karmaşıklık olgusunu göğüsleyebilmelidir (Morin, 2014). Karmaşıklık (complexus) birlikte örülmüş, dokunmuş anlamına gelir. Gerçekten de öğenin parçaları birbirinden ayrılmaz olduğu zaman ve bilginin konusu ve bağlamı ve parçayla bütün arasında, parçaların kendi arasında karşılıklı bağımlı, etkileşimsel ve aktif bir doku olduğunda karmaşıklık vardır. Bu birlik ve çokluk arasında bir bağdır. Eğitimi dromokratik bir ortamda açmaza sokan en önemli sorun karmaşık olana, çokboyutlu bir yaklaşımla bağlama ve bütüne uygun bir genel zeka geliştirememesidir. Bunun sonucu olarak bilgi alanındaki devasa ilerleme, displinler arasındaki uzmanlaşmalarla gerçekleşmektedir. Fakat bilginin gelişimindeki dromokratik ilerleme bütün içindeki parçaları çözümlemeye yarayan karmaşıklık olgusunu gözardı etmektedir. $\mathrm{Bu}$ durum katı uzmanlaşmayla bilginin anlamlandırma becerisinde gerilemeye sebep olarak akla uygun genel zekanın eğitim ile çatışmasına yol açabilmektedir (Morin, 2014).

2015 yılı uluslararası eğitim değerlendirme testi PISA sonuçlarında Türkiye, 70 ülke içinde fende 52'inci, matematikte 49'uncu, okumada 50'inci sırada yer alarak 2003'teki seviyesinin de gerisine düştü. Türkiye yıllar boyu dromolojik bir eğitim tarzıyla öğrencileri gerçek hayattan kopuk bir şekilde okul denilen dromokratik mekanlarda zamandan bağımsız bir şekilde güncel olmayan bilgilerle doldurmaktadır. Oysa, gerçek hayatta karşılaştığımız sorunların çözümleri, matematik, fen ve felsefe gibi alanlardan çıkmaktadır. Öğrencilerine nedensel ilişkiler kurabilmeleri için analitik düşünme becerisi veren eğitim sistemleri, ilk olarak öğrencilerinin sorun alanlarını fark etmelerini, bilgiyi yorumlayarak günlük hayatla bağlantı kurabilmelerini sağlamaktadırlar. Buna göre modern dünya, bilişsel, sosyal ve duygusal kaynaklarınızı nasıl kullandığınıza göre sizi ödüllendiriyor. Google zaten her şeyi biliyor. Okulda öğrendiğiniz birçok şeyi akıllı telefonunuz yapıyor. Hedef, akıllı telefon kadar akıllı olmak değil ama insan doğasının farklı yeteneklerini kullanabilmektir (Altıntaş, 2018). 
Virilio (1998) hız kavramının toplumsal hareketliliğe olan etkisine ve toplumsal dönüşümde kitlelerin akışkanlığı konusuna da değinir. Buna göre, dolaşımın ontolojik etkisi dromokrasinin ürettiği hız ve haz kavramının aksine kendini toplumsal olaylarda kitlelerin hareketi olarak hissettirir. Bu büyük bir harekettir çünkü dolaşım özgürlügü̈n ve hür iradenin ifadesidir. En küçük bir grup dinamiğinin yolculuğa çıkardığı insanların dönerken içlerinde taşıdığı birlik içinde olma duygusudur.

Egemen güçler, özgür insana ait varoluşsal dolaşma hakkının kendilerinin iktidarının temellerini yıkacağını bilmektedir ve kitleleri sokaktan uzak tutacak sistematiği oluşturmakta beceri sahibidirler. Kitle bir halk değil, bir toplum değil yoldan gelip geçenler yığınıdır; devrimci bir topluluk makinenin teknik aracısı olarak üretimin yapıldığı yerlerde bizzat kendi gücünü yönetebildiği sokaklarda çoğalabilir (Virilio, 1998). Çünkü sokak alt, orta gelir gruplarının iktidara meydan okuyacağı yegâne yerdir. Bu istenç, sadece yoldan gelip geçenler yığını olan kitlelerin değil aynı zamanda egemenlerin de sahip olma mücadelesi verdiği bir güçtür.

Modern devletler olarak adlandırılan egemenler halkın sokağa çıkmasının ancak yeni bir yaşam tarzıyla önlenebileceğinin bilincindedirler ve otoriter tutum üreten işlevselci aygıtları aracılığıyla önceden tanımlanmış bir toplum oluşturmaktadırlar. Bu oluşum, toplumun zihnindeki hakikatin caydirıldığı ahlâkın, erdemin, doğanın ve insanın neo-ahlâkın, neo-erdem, neodoğa ve neo-insanla ikame edildiği bir dromokrasi evreninde ortaya çıabilir. Özge bir deyişle, her şey yenileşmekte öz değişmemektedir. Yeni eskinin yenisidir. Özü ifade eden bir şey yoktur. Dromolojik eğitim, ne yazık ki insanı Sokrates dönminden daha gerilere götürerek insanı eğitimin merkezinden, özne konumundan alıp nesne konumuna dönüştürmüştür. Sokratik düşünce, yalnızca insanı değil, aynı zamanda her bir bireysel insan varlığını felsefî düşüncenin mutlak merkezi hâline getirmiştir (Versenyi, 2007: 129). Burada eğitimin ana gayesi, her bir insanın, içinde var olan kendi cevherini keşfetmesini sağlamaktır. İnsan, diğer varlıklardan farklı olarak yeryüzünde eksik olan tek varlıktır. Ancak insan aynı zamanda doğasında önemli bir potansiyelle de doğar ve eğitimle bu potansiyeli gelişme gösterir. İnsan, doğası itibariyle ne hayvan ne de tanrı olmadığı için, iyilik ve bilgisizlik, erdem ve kusur bakımından yetkinlikten yoksundur ve eksikliğinin bilincinde olduğun- 
dan, düzelmeyi ve gelişmeyi arzular. Öyleyse insan, doğuştan itibaren gelişmeye, inkişaf etmeye aşkla bağlıdır ve günümüz dromolojik eğitiminden çok farklıdır.

Kısaca ifade etmek gerekirse, insanı önceleyen aydınlanma dönemi bilginin tinsel tutumlarla değil akıl yoluyla üretileceği düşüncesine yol açmıştır. İnsanlar artık her şeyi alıp götürmek, yağmalamak, yemek, yutmak ve güdümlemek istemektedirler. Bu gelişimle birlikte insanlık kendisi için kapitalizmi semirtmek adına tükettikçe yok olan-yok oldukça tüketen bir sistem oluşturmuştur. Bu sisteme gerekli insanları tasarımlama görevi, eğitim denen toplumsal kuruma verilmiştir. İktidarların ideolojik aygıtı (Althusser, 2006) olarak desenlenen ve yaşamları yeniden üreten eğitim; bilginin insan doğasına anlam vermesi, insanların düşünce ve eylemlerini ayırabilmek için bilgiyi kullanması yerine ne yazık ki dromoloji biliminin ışığında bilgiyi üreten okulun da insanları bir nesneye dönüştürdüğü görülmektedir. Örneğin Aritmetik. Bilgi insanlığa yapılacak bir hizmette aracı olarak kullanılacağı gibi sanayi sistemine köleliğin bir amacı olarak da kullanılabilmektedir. Aritmetik bilimi kapitalist ideolojinin terimleriyle öğretilirse kâr ve zarar hesabı yaparak bilgi köleliğinin bir aracı haline getirilebilir (Spring, 2010). Bu kölelik öyle bir köleliktir ki hayata dair hiçbir geçerliliği olmayan en zor formüllerle en karışık denklemleri çözmeye çalışan bir çocuk, günümüzde hayata dönük en kolay pazar-market hesaplarını yapamaz durumundadır.

\section{Dromolojik Okul ve Atık Bedenler}

Sokağa çıkmasına izin verilmeyen öğrencilerin hapsedildiği, her an öğrencilerin izlendiği panoptik hapishane ya da hipermarket biçiminde kurgulanmış okullar gençlerin yalnızca bedenlerinin baskı altında tutulduğu diploma dağtan kurumlara indirgenmiş yerler olarak işlevlerini yerine getirmektedir. Bir ülkenin bütün okullarında tek bir merkezden yapılan müfredatın işleniyor olması, okulların coğrafî ve bölgesel şartlar dikkate alınmadan aynı tarihte başlayıp bitmesi, panoptik bir yönetim anlayışının bir ürünüdür (Foucault, 2005).

Bir siren sesiyle çalışmaya başlayıp, bir sonrakiyle mola veren, diğeriyle yemek yiyen ve en son sirenle fabrikayı terk eden işçinin, panoptikon hapishanesine fiziken girmesine gerek yoktur, çünkü hayat tarzı olarak buna tabi olmuştur ve bu tarz, onun için normaldir. Büyük kapatılmanın gerçekleştiği 
asıl mekan, insan ruhudur (Ceylan, 2015). Akıl hastanesi, hapishane ve eğitim kurumları gibi normların dışına çıkmış ruhları terbiye edip iyileştirmek için var olan dromomlojik kurumlarsa bu büyük kapatılmanın karanlık yüzünü gizleyen sözde insancıl okullardır.

Çağımızda okulların çoğu devasa nüfusuyla genç dimağları kendine çekmektedir. Burası ruhun ve zihinlerin içeriye giremediği, nesnelerce oluşturulan işlevsel ve yönlendirilmiş, sorunun parçası olarak, sorunun çözümü değil, insanın yeniden tasarlandığı bir mekânlardır. Hayatın anlamı okulun kapısından içeri girildiği anda değişir. Okulda hayat çoktan seçmeli bir testtir. $\mathrm{Bu}$ testlerin soruları ne hayatı ögrretmekte ne de ne de pratiklemektedir. Cevaplar sadece kısırdöngülerin cevaplarıdır. Her sorunun cevabında dört öğrenci yok olurken sadece bir öğrenci vardır. Bu varlık sadece insani kodların ve ruhun sinanmasıdır. Örnek olarak vermek gerekirse, Türkiye'de 2012 yılında yapılan ilköğretimden ortaöğretime geçiş sınavı olarak yapılan SBS sınavına 1.075.533 öğrenci katılmıştır. Türkiye genelinde bulunan Fen Liselerinin aldığı öğrenci yüzdelik dilimi ise ortalama 1,5 olarak belirlenmiştir (Ĕ̆itim Haberleri, 2012). Bu sınav sonucuna göre doğru seçenek olarak belirlenen 16.130 çocuk seçilmiş ve geri kalanı da yanlış seçenek olarak kabul edilerek toplumsal atık statüsüne konmuştur.

Eğitim, insan türünün birliği düşüncesinin türün çeşitliliği düşüncesini ve türün çeşitliliği düşüncesinin de türün birliği düşüncesini ortadan kaldırmamasını gözetmelidir. İnsanın hem birliği hem de çeşitliliği ontolojik bir geçerliktir. Birlik sadece insanın biyolojik özelliklerinde bulunmaz. Çeşitlilikte, insan varlığının ruhsal, kültürel, toplumsal özelliklerinden ibaret değildir. İnsanın birliği içinde bir de biyolojik çeşitlilik vardır. Yani bu zihinsel, duygusal ve ruhsal bir eşgüdümle birlikte ortak üretici ve örgütleyici özellikleri meydana çıkarır. İnsanı anlamak onun çeşitlilik içindeki birliğini ortaya çıkarmakla gerçekleşebilir (Morin, 2014).

Dromolojik eğitim aracılığı ile insanı yetiştirmek, sıralamak, yaftalamak, ölçmek ve seçmek gayretleri çeşitlilik ve birlik kavramlarını yok ederek atık bedenleri öne çıkarma eyleminden başka bir şey değildir. Oysa eğitim insanın çok yönlü yazgısını kendi kendine seçme becerisini kazandırmalı ve örnek insan olarak sahneye çıkarması gerekir. İnsanın yazgısı, toplumsal yazgıyı, tarihsel yazgıyı ve birbirinden ayrılamaz tüm yazgıları insan denen öznede toplayarak yeryüzü yurttaşları olarak kökleşmemize neden olacaktır. 


\section{Yitik Paradigma: Yeni Okul Kurgusu}

Dromoloji çağının dromokratik okulları hayatımıza anlam, bakışlarımıza bir perspektif ve ruhumuza ufuk kazandırabilecek bir kurumdan ziyade, düzenleme biçimi nedeniyle art arda gelen eşdeğerli görünümlere, aynısının tıpkısı imajlara benzeyen reklam panolarına, ürünlerden oluşan raflara ve tezgâhları andıran total bir dijital ekrana benzemektedir (Baudrillard, 2011). Akıl ve vicdan gözünde değer taşıyan hayat pratikleri uzun zamandır yapılan toplumlarda ruh da alıclık kabiliyetine sahip olmaktadır. Ve alıcı ruhlar o toplumda kendi küllerinden doğan nesiller her alanı okul yapmaktadırlar. İtaat okul, isyan da okul oluyor. İsyanı bayrak yapan Fransız ihtilalci gençleri de yetiştiren bu okullardır (Topçu, 2015). Toplumları sokaktan soyutlayarak fraktal bir şekilde simüle bendenler yaratan şimdinin okulları değil. Emileé eğitiminden sonra, hayatın son zorunluluğunun ölüm olduğunu kabul edecek kadar özgür olmayı ve özgürlüğün hükümette değil, özgür kişinin yüreğinde olduğunu öğrendiğini ifade etmiştir (Rousseau, 2009).

Zihinsel dünyaları hakikat yerine teknolojik cihazların ürettiği hız ve her an burdalık realitesiyle yaşamları kontrol altına alınan çocuklar, irrasyonel yaşamaya zorlanmakta ve sokağa çıkmaları engellenmektedir. Egemenler dolayısıyla muratlarına ermiştir, sokaklar artık sanal âlemin sokaklarıdır. Sokakları gezmeye gerek yoktur çünkü sokağa yerleştirilmiş kameralar aracıl1ğıyla sokağı izleyebilir, istediğiniz yeri sanal olarak ziyaret edebilirsiniz. Okulların görevi de dünyanın kendisini değil sanalını keşfeden insanlar yetiştirtmek ve en iyi, en hızlı ve en karmaşık cihazı kusursuz kullanabilen bireyler yetiştirmektir. Oysa sokakta yürüyen, oksijeni içine çeken, ağaçların yeşilini gören özgür bir insan için her şeyi bilmek seçim kaynağı iken sanal dünya için üretilmiş entelektüeller için her şeyi bilmek sadece seçilme kaynağı olmaktır (Virilio, 1998). Böylece modern, hız merkezli panoptik eğitim ile görevini gerçekleştiren okulun materyalist kesinliği mutlak pragmatizme dönüşmektedir.

Oldukça bilinen bir hikâyedir. Filipinlerde sekiz yüzyıldan bu yana insanlarla ilişki kurmadan yaşayan Tasaday kabilesi sonunda antropologlarca keşfedilmişti (Dumont, 1988). Ne var ki Tasaday kabilesi antropologlarca bulunur bulunmaz, kapatılmış oldukları mezarda açık havaya çıktığında toz haline gelen bir mumya gibi yok olmaya başlamıştı, çünkü onların sekiz yüz 
yıllık özgünlükleri ve dokunulmamışlıkları yok olmuştu (Ozen, 2017). Dromolojik evrende Etnolojinin yaşaması için nesnenin yani Tasaday kabilesinin ölmesi gerekmektedir. Fakat Filipinler hükümetinin aldığı kararla etnologların kabile üyelerine dokunması ve ilişkiye girmesi yasaklanarak kendi bağlamlarında kendi başlarına yaşamaları için karar alındı. Hız ve haz çağında ilk kez nesne kazanarak bekâretini korumuştur. Ormana geri gönderilen kabile yine de bir simülasyon modeline dönmüştür (Baudrillard, 2011), çünkü kabile tekrar keşfedilerek/yaratılarak varlıklarını Etnolojiye borçlu olmuşlardir (Dumont, 1988).

Bu anlatıdan yola çıkarak okula yeni başlayan bir çocuğu, Tasaday kabilesiyle karşılaştıracak olursak; eğitim sistemi, okul ve en önemlisi öğrenci için sonuç daha vahim olacaktır. Kendi bağlamında yaşayan bireyler bilim arenası aktörü, Etnoloji, öğretmen tarafından Tasaday kabilesi gibi gerçek bağlamından alınarak kapitalist sistemin çarklarından olan ve durmanın ölüm olarak sloganlaştırıldığı hız ve hazzın oluşturucusu okula götürülmektedirler. Çocuklar Tasaday kabilesi gibi açık hava, okula, girdiği an toz haline gelen mumya gibi yok olmaya başlamaktadır. Ne yazık ki öğrenciler Tasaday bireyleri kadar şanslı değildir. Çünkü çocuklar bağlamından yani gerçeklikten koparılarak yaşamın kendisinin değili olan ve bütün şekillendirmenin kapitalist düzenin araçlarından olan sanal ortamlarla biçimlendirilmiş bir bağlama sokularak öldürülmekte ve neo-hakikate çevrilmektedirler. Aslında öz öldürülmektedir. Bilimin yaşaması için Tasaday'lların ölmesi gerekmekteydi fakat ilk kez bilim kaybetmişti. Ama eğitime geri döndüğümüzde bu kez bilim-okul kendi varlığını devam ettirebilmek için çocuğun özünü öldürerek kendi varlığını devam ettirmektedir.

Egemenin arzusuna hizmet ederek bedenleri sokaktan alıkoyan eğitim, okulda yok edilen ruhun ve şuurun kinetizminin ssrarlı bir biçimde kavranmasından başka bir şey olmayan kısır döngüdür (Virilio, 1998). Bu döngüden kurtulmak ne zordur ne de kolaydır. Kaçmak yeterlidir. Oysa okul sisteminden kaçmak sağlıklı bir çocuk için fasit daireden kurtulmak anlamına gelirken, biz eğitimciler için okul terki suç veya nedeni araştırılması gereken bir fenomen olur. Ailelerin ilk yedi yılda üretici eyleminin daha sonra nihai anamala dönüştürülmesi hareketinin mimarı olan okul gerçekliğin egemen aktörü olarak tarih sahnesinde rolünü başarılı bir şekilde oynamaktadır. 


\section{Değişen Hayat ve Sathileşen Okul}

Mekânların ve kentlerin dönüştürülmesi ya da yeniden düzenlenmesi toplum mühendisliğidir. Hitler'de halkına yollar vaat ederek sokakları boşaltmayı başarmıştır. Volkswagen ortaya çıkmıştır. Büyük bir organizasyon eşliğinde yerel ve ulusal örgütlenmeler aracılığıyla sadece kent içi yollar değil, kentler arasında geniş otobanlar inşa edilmiştir. Dönem artık hareketin, ivmenin, hızın ve hızlanmanın dönemidir. Bütün bunlar taşıtlar yardımıyla yapılmıştır (Virilio, 1998). Artık bütün temel anlayışlar değişmiştir. Ortaçağ ve Yakınçağ sanat eserlerine bakınız; tarlalar belirleyicidir. Tarlaların, dağların ve ovaların arasından kıvrılarak giden yollardır. Düz çizgiye sahip sadece tarlaların sınırlarıdır ve tarlalar en önemli varlıklardır. Yollar ise coğrafyanın en değersiz mekânlarıdır. Oysa yaşamın içine yerleştirilen hız sayesinde bu anlayış değişecektir ve egemenler ikinci bir tahakküm aracı olarak üzerinde hızlı yaşamın pratiklendiği, teknik vasıtaların baş döndüreceği düz çizgi şeklinde yollar ortaya çıkmıştır. İnsanların üzerinde yürüdüğü, hayatlarının bir parçası olan sokak ve caddeler sadece hız makinası olan araçlara terk edilen ruhsuz yerlere dönüşmüştür (Virilio, 1998).

Egemenin bir arzusu bir kez daha yerine gelmektedir. Halkın artık sokakta olmaması sağlanmıs, sokakta olma ihtimali olan zamanlarda da yollarda olması sağlanmıştır. 1848 yılında gerçekleşen üçsekiz devrimi sayesinde insanlar sekiz saat çalışma, sekiz saat dinlenme ve sekiz saat uyku ile bütün çalışanlar, alt ve orta gruptaki insanlar birlik yaratmanın özel onuruna sahip olmuşlardı (Virilio, 1998). Fakat günümüzde sekiz saatlik eğlencenin gizem içinde kalan gerçek yüzü açığa çıkmıştır. Eğlence, ücretli izindir. Gezdikçe, hızlı otobanlarda deliler gibi yol aldıkça sahip olunan bir mutluluk oluşmuştur. Bu mutluluk gezmenin değil hızın ve hazzın insan ruhunda sebep olduğu bir dromolojik değişimdir.

Bu değişimin stratejik şeması sorumluluklarından kurtulmak için çocuklarının ruhunu ve bedenini okula devreden ailelerde ve bizatihi okulun kendisinde görülmektedir. Okulun verdiği eğitimle öğrencilerin hayata yönelik olumlu davranışlar kazanması gerekir. Bu olumlu davranışların en önemlilerinden birisi evrensel ahlak anlayışıdır. Sahip olduğumuz iradenin otonomisi bizden kendi isteğimizle üstlendiğimiz ödevleri yerine getirmemizi bekler. Ödev vicdan tarafından da denetlenen ahlaki bir eylemdir. Manevi olan her 
duygu ve kavram bir vatandaş olarak öğrencilerden iyi bir ödev insanı olmaların beklemektedir (Bergson, 2013; Akarsu, 2000). Oysa eğitimin doğası ve toplumsal işlevi göz ardı edilerek, pedagojinin hiç bir mantıklı açıklamasında olmayan bir zihniyetle turizm kazansın diye okullarına tatil veriliyor. Dromolojik bir yaşam biçimi sayesinde insanlar hız ve haz içinde yaşamanın peşinden koştur(tul)uyorlar. Birçok bakımdan ilerlemiş ülkelerin bazılarında okula gitme oranı bir yıl içerisinde 243 gün seviyesine ulaşırken, Türkiye'de ise daha çok tatil ve daha çok kapitalizmin kazanması uğruna öğrencilerin hem yaşamsal ve öğrenme motivasyonuna hem de okula karşı olumsuz tutum edinmesine neden olunmaktadır. Bu sayede okulun kavram olarak oluşturduğu totaliter ve dromokratik yapı-ne yazıktır ki-sıfır toplamlı bir oyunun uç örneğidir: Yanlızca kazananlar ve kaybedenler vardır. Toplumu oluşturan herkes kazanan olurken bir tek kaybeden vardır. Bu kaybedenler eğitimin temel paydaşları olan öğrenci, öğretmen ve ailedir. Dolayısıyla doğası gereği okul, kaybeden kişilere ayrıcalık tanımaktadır (Illich, 2012: 97).

\section{Sonuç}

Viriliónun toplum çözümlemesi post-modern dünyadaki dönüşümleri çözümlemek için farklı bir perspektif sunmaktadır. Buna ilave olarak bir yönetim aracı ve ideolojik bir ayraç olarak ortaya koyduğu hız-politika olgusu askeri, mekansal, ekonomik değişim dinamiklerini küresel düzenin işleyişini çözümleyecek ve sahte akılsallığı ortaya koyacak bir kavramsal çerçeve sunmaktadır. Hız ve politika aracılığıyla dromokratik anlayış güncel ilişkilerden bilimsel gelişmeye kadar her şeyi etkilemektedir. Eğitiminde içinde olduğu her sosyolojik kurum ve kavram dromoloji tarafından derinden etkilenmektedir.

Günümüzün küreselleşme eğilimi zaman-mekan ilişkilerinin yeniden biçimlenmesi olarak küresel akışı toplumsal ilişkilerin merkezine koymakta (Aykutalp, 2017) ve determinist olarak kabul edilen zaman-mekan genişlemesi olgusunu karmaşıklık evreninin kalbine yerleştirmektedir. Dolayısıyla enformasyon toplumu doğrusal (linear) ve kararlı (determinist) olan her bir yaklaşımı reddeden yeni bir toplum ortaya çıkarmaktadır. Fakat dromokratik evrende imsan yetiştiren eğitim kurumlarının ürettiği bilgi akla uygunluk ilkesine uymamakta ve karmaşık evreni çözümleyememektedir. Karmaşıklık birlik ve çokluk arasında bir bağdır. Dromokratik eğitimi açmaza sokan en 
önemli sorun; karmaşık fenomene, çok boyutlu bir yaklaşımla bağlama ve bütüne uygun bir genel zekâ geliştirememesidir. Böylece dromokratik okul, bütünü parçalara indirgeyerek açıklayan bir yöntem geliştirerek katı uzmanlaşmayla bilginin anlamlandırma becerisinde gerilemeye sebep oldu. Bu da akla uygun genel zekânın öğretim sistemleriyle çatışmasına yol açmaktadır. Oysa insanı önceleyen okul anlayışında, çocukların, enformasyonla doldurulması gereken sabit bir entelektüel kapasiteyle doğduğuna dair eğitim iklimi ortadan kalmaya başlamıştır.

Artık entelektüel yetenek, eğitim yoluyla geliştirilebilen bir dizi beceri olarak görülmektedir. Toplum, bir yanda sıradan insanların olduğu, diğer yanda ise uzmanlar ve otoritelerin olduğu kutuplaşmadan uzaklaşmıştır. Eğitimde gittikçe artan bir şekilde, öğrenciler, kendilerine öğretileni daha fazla sorgulamakta ve öğretmenlerden, öğretimde, öğrencinin daha aktif ve eşit rol oynadığı öğrenmeyi kolaylaştırıcı rol oynaması istenmesine rağmen dromokratik okullar entelektüel sermayenin kaybolması gerçeği ile yüzleşememektedir.

İktidarların ideolojik aygıtı (Althusser, 2006) olarak kurgulanan ve yaşamları yeniden üreten eğitim; bilginin insan doğasına anlam vermesi, insanların düşünce ve eylemlerini ayırabilmek için bilgiyi kullanması yerine ne yazık ki dromoloji biliminin ışığında bilgiyi üreten okulun da insanları bir nesneye dönüştürdüğü görülmektedir. Sokağa çıkmasına izin verilmeyen öğrencilerin hapsedildiği, her an öğrencilerin izlendiği panoptik hapishane ya da hipermarket biçiminde kurgulanmış okullar gençlerin yalnızca bedenlerinin baskı altında tutulduğu diploma dağıtan kurumlara indirgenmiş yerler olarak işlevlerini yerine getirmektedir.

Bir ülkenin bütün okullarında tek bir merkezden yapılan müfredatın işleniyor olması, okulların coğrafî ve bölgesel şartlar dikkate alınmadan aynı tarihte başlayıp bitmesi, panoptik bir yönetim anlayışının bir ürünüdür (Foucault, 2005). Bir siren sesiyle çalışmaya başlayıp, bir sonrakiyle mola veren, diğeriyle yemek yiyen ve en son sirenle fabrikayı terk eden işçinin, panoptikon hapishanesine fiziken girmesine gerek yoktur, çünkü hayat tarzı olarak buna tabi olmuştur ve bu tarz, onun için normaldir. Büyük kapatılmanın gerçekleştiği asıl mekan, insan ruhudur (Ceylan, 2015). Akıl hastanesi, hapishane ve eğitim kurumları gibi normların dışına çıkmış ruhları terbiye edip iyileştirmek için var olan dromomlojik kurumlarsa bu büyük kapatılmanın karanlık yüzünü gizleyen sözde insancıl okullardır. 
Eğitim, insanın türünün birliği düşüncesinin türün çeşitliliği düşüncesini ve türün çeşitliliği düşüncesinin de türün birliğini ortadan kaldırmamalıdır. İnsan ontolojik yapısının geçerliği olan birlik ve çeşitlilik zihinsel, duygusal ve ruhsal bir birlikle birlikte ortak üretici ve örgütleyici özellikleri meydana çıkarır. İnsanı anlamak onun çeşitlilik içindeki birliğini ortaya çıkarmakla gerçekleşebilir. Oysa ki dromolojik eğitim ile insanı yetiştirmek, sıralamak, yaftalamak, ölçmek ve seçmek gayretleri çeşitlilik ve birlik kavramlarını yok ederek atık bedenleri öne çıkarma eyleminden başka bir şey değildir. Dromoloji çağının dromokratik okulları hayatımıza anlam, bakışlarımıza bir perspektif ve ruhumuza ufuk kazandırabilecek bir kurumdan ziyade, düzenleme biçimi nedeniyle art arda gelen eşdeğerli görünümlere, aynısının tıpkısı imajlara benzeyen reklam panolarına, ürünlerden oluşan raflara ve tezgâhları andıran total bir dijital ekrana benzemektedir.

Dromokratik eğitim çocukları hayattan uzaklaştırıp okul denilen fiziksel mekanlara hapsetmektedir. Böylece dromoloji ışı̆̆ında okulların görevi de dünyanın kendisini değil sanalını keşfeden insanlar yetiştirmek ve en iyi, en hızlı ve en karmaşık cihazı kusursuz kullanabilen bireyler yetiştirmektir. Oysa sokakta yürüyen, oksijeni içine çeken, ağaçların yeşilini gören özgür bir insan için her şeyi bilmek seçim kaynağı iken sanal dünya için üretilmiş entelektüeller için her şeyi bilmek sadece seçilme kaynağı olmaktır. Böylece modern, hız merkezli panoptik eğitim ile görevini gerçekleştiren okulun materyalist kesinliği mutlak pragmatizme dönüşmektedir

İnsanın birey olarak içinde doğup geliştiği aile, okul ve meslek gibi kavramların bütünü önce millet sonra insanlık olarak kabul edilmektedir (Yücel, 2012). Fert merkezde, cemiyet muhitte olduğuna göre merkeze en yakın daire aile, okul ve meslek olarak karşımıza çıkmaktadır. İnsanları hız ve haz bağımlısı yapan egemenlerin takip ettiği ve merkeze koyduğu kapitalin merkezden alınıp hak eden insana hakkın iadesi ancak hakikatin ışıttığını yayma görevi olan kadim okul ve eğitimle olacaktır. İnsanı hakikat amacına yöneltecek, sıradan deneyim içindeki olasılıkların geliştirilmesini sağlayabilecek okul geleceğin bilimine ulaşmak için bakış açısını değiştirerek, gençleri hayal âlemine sürükleyerek, gelecekten koparması değil, onları ruhlarının ufuklarına yürüyen özgün fertler olarak potansiyellerini keşfetmelerine imkân vermelidir. Aksi halde eğitim ve okulun haz ve hız arasındaki fraktal, speküler ve paradoksal epistemolojisi; insan ruhunu teknik makinaya dönüştürmeye devam edecektir. 


\title{
EXTENDED ABSTRACT
}

\section{Dilemmas of Education and Schools in Dromocratic Societies: A Paul Viriloic Analogical Analysis}

\author{
Hamit Özen \\ Eskisehir Osmangazi University
}

Developed societies establish superiority over other societies through education in every field, adapting to change and transformation more rapidly. One of the most important characteristics that will shape the future, is the intellectual knowledge and skills that a person will possess. Thus, these qualifications are obtained best in schools. The school, one of the most important cultural and political devices generated by modern times, is moving away from its main purpose, so called building a more just, more humanist world. In general, thinkers make use of various philosophical theories and concepts to better analyse social transformations. Virilio (1998), on the other hand, makes the analysis of society which transforms urban spaces with the construct of war logic and war model of the capitalist system in his book "Speed and Politics."

The main problem of this study are the students who cannot be equipped with basic human virtues such as critical thinking, creativity, flexibility, distant from astonishment and aesthetical feeling, dexterity and honesty due to the low value pedagogical education system which is constructed on today's world, and the school which cannot deliver mentioned concepts through education. In addition to this, another topic is to question the existential reality of the education system that cannot measure all the outputs of its students and makes them addicted to speed and pleasure with the oversimplified fallacy of choosing only one right and four mistakes. During this query, Paul Virilio's concepts regarding to Speed and Policy becomes guiding.

Today, the physical reality of institutions such as education and school are destroyed by technological devices and virtual education environments, and they are, dromologically, dominated by the desire of speed, rush and acting swiftly. The most important pain point of the knowledge produced by dromocratic educational institutions is that it does not comply with the principle of reasonableness. This situation can lead to a conflict by means of rigid 
specialization (Morin, 2014) between rational general intelligence and education by causing a decrease in the ability to make sense of knowledge. Unfortunately, schools are where this paradox is generated.

Schools are designed as panoptic prisons or hypermarkets where students are not allowed to go out on the streets, rather imprisoned and monitored at all times, and the schools function as places which are reduced to diplomadistributing institutions where the bodies of young people are kept under pressure (Foucault, 2005). That the curriculum which is prepared by a single centre, thought on all schools of a country, and the schools start-end dates being same regardless of the geographical and regional conditions are a product of a dromological management conception. Life at school is a multiplechoice test. The questions of these tests neither teach nor practice life. The answers are just answers to perverse cycles. There remains only one student while the other four perishes along the way of answering each question. Those who are perished are the students labelled as waste bodies.

The dromocratic schools of the age of dromology are not an institution that can give meaning to our lives, a perspective to our gaze and a scope for our soul, rather an institution that resembles the successive equivalent appearances due to the way of configuration, billboards that look exactly the same as images, shelves of products and a total digital screen resembling countertops (Baudrillard, 2011).

The mission of schools is to raise people who discover the virtual, rather than the world itself, and raise flawless individuals who can use the best, fastest and most complex device. For a free person who walks on the street, absorbs oxygen and sees the green of trees, for whom knowing everything is a source of choice, whereas, for the intellectuals, who are created for the virtual world, knowing everything is only being a source of designation (Virilio, 1998). Thus, the materialistic certainty, which the school fulfils its mission with modern, speed-centred panoptic education, transforms into absolute pragmatism.

Transformation or reorganization of spaces and cities is social engineering. Hitler also managed to clear the streets by promising roads to his people. Through local and national organisations accompanied by a large organization, not only urban roads but also wide highways between cities were built. The era is now the era of motion, acceleration, velocity and momentum. All this has been done with the help of vehicles (Virilio, 1998). With the education 
delivered by the school, students should acquire positive behaviours towards life. One of the most important of these positive behaviours is the universal understanding of morality. However, nowadays, schools are given holidays for tourism income with a mentality that is not in any logical explanation of pedagogy, ignoring the nature and social function of education. Because of a dromological way of life, people pursue, or enforced to pursue, life of speed and pleasure. In many respects the attendance period of schools in some of the developed countries reaches 243 days within one year, while in Turkey, for the sake of capitalism and more holidays, students are made to procure negative attitudes towards not only vital and learning motivation but also towards school.

The whole of concepts such as family, school, and profession in which a person is born and developed as an individual is regarded as first the nation and then the humanity (Yücel, 2012). Since the individual is in the centre and the community is in the neighbourhood, the closest circle to the centre appears successively as family, school and profession. The reinstatement of the rights to the deserving person will only be possible through the autochthonous school and education, which is the duty of spreading the truth by removing the capital from the centre, which is followed by the rulers who make people addicted to speed and pleasure and puts the capital in the centre. The school should make it possible, which will lead people to the purpose of truth and enable the development of possibilities in ordinary experience, by changing the perspective to reach the science of the future, leading young people into the realm of imagination, not detaching them from the future, but by allowing them to discover their potential as authentic individuals walking to the scopes of their souls. Otherwise, the fractal, specular and paradoxical epistemology of education and school between pleasure and speed will continue to transform the human spirit into technical machinery.

\section{Kaynakça / References}

Akarsu, B. (2000). Immanuel Kant'in ahlak felsefesi. İstanbul: İnkılap.

Akın, U., ve Arslan, G. (2014). İdeoloji ve eğitim: Devlet-eğitim ilişkisine farklı bir bakış. Trakya Üniversitesi Eğitim Fakültesi Dergisi, 4(1), 81-90.

Althusser, L. (2006). İdeoloji ve devletin ideolojik aygıtlan (Çev. A. Tümertekin). İstanbul: İthaki. 
Altıntaş, Ö. (2018, 27 Aralık). PISA direktörü Andreas Schleicher: Türkiye bilgiyi pratiğe geçirmeyi öğrenmeli. BBC News/Türkçe https://www.bbc.com/turkce/haberler-turkiye-42481321 adlı siteden 20.11.20179 tarihinde indirilmiştir.

Altun, G. C. (2015). Bir modernite olgusu olarak hızın sanatta gösterimi. Yayımlanmamış Yüksek Lisans Tezi, İstanbul Üniversitesi, İstanbul.

Atmaca, T. (2019). Sınıfsal habitus ve amor fati'nin kesişim noktası: Meslek lisesi öğrencilerinin gözünden dezavantajlı eğitim hayatlarının değerlendirilmesi. Ĕ̆gitimde Nitel Araştırmalar Dergisi, 7(3), 899-920.

Aykutalp, A. (2017). Hız siyaseti: Paul virilio'nun dromoloji kuramı. International Journal of Social Science. 61, 429-440, Doi: http://dx.doi.org/10.9761/JASSS7317

Aypay, A., Sever, M., ve Demirhan, G. (2012). Üniversite öğrencilerinin sosyal ve akademik entegrasyonu: Boylamsal bir araştırma. Gaziantep University Journal of Social Sciences, 11(2), 407-422.

Baudrillard, J. (2011). Simulakrlar ve simülasyon (Çev. O. Adanır). İstanbul: Doğu Batı Yayinları.

Beighton, C. (2017). Closed circuit? Flow, influence and the liquid management of learning and skills. Discourse, 38(4), 603-618.

Bergson, H. (2013). Ahlakın ve dinin iki kaynağı (Çev. M. M. Yakupoğlu). İstanbul: DoğuBat.

Bourdieu, P. (1973). Cultural reproduction and social reproduction. In R. Brown (Ed.), Knowledge, education, and cultural change (p. 71-84). London: Tavistock Publications.

Boyd, V. (1992). School context: Bridge or barrier to change? Austin, TX: Southwest Educational Development Laboratory.

Ceylan, C. (2015). Foucault ve ironik özgürlük. Akademik Bakış Dergisi, 51, 183-194.

Dumont, J. P. (1988). The Tasaday, which and whose? Toward the political economy of an ethnographic sign. Cultural Anthropology, 3(3), 261-75. doi:10.1525/can.1988.3.3.02a00030

Eğitim Haberleri (2012, 12 Temmuz). İlköğretim 8. sını̈öğrencilerinin girdiği Seviye Belirleme Sınavinin (SBS) sonuçları açılandı. Sabah. https://www.sabah.com.tr/egitim/2012/07/12/sbs-sonuclari-aciklandi adlı siteden 18.09.2017 tarihinde indirilmiştir.

Ergün, M. (2015). Ĕgitim sosyolojisi. Ankara: PEGEM.

Foucault, M. (2005). Büyük Kapatılma - Seçme Yazılar-3 (Çev. I. Ergüden, O. Akınhay ve F. Keskin). İstanbul: Ayrint.

Geuss, R. (1981). The idea of a critical theory: Habermas and the Frankfurt School. Cambridge University Press. 
Illich, I. (2012). Okulsuz toplum (Çev. M. Özay). İstanbul: Şule Yayınları.

Liston, D. P. (1988). Capitalist schools: Explanation and ethics in radical studies of schooling. New York: Routledge.

Mermutlu, A. (2018). Hız semptomları: geç-modern zaman rejiminde belirsizlik, dolayımsızlık, eşzamansızlık. Fırat Üniversitesi Sosyal Bilimler Dergisi, 28(1), 245-260.

Morin, E. (2014). Geleceğin eğitimi için gerekli yedi bilgi (Çev. H. Dilli). İstanbul Bilgi Üniversitesi Yayınları: İstanbul.

Okuyan, H., ve Taslaman, C. (2018). Jean Baudrillard'ın simülasyon kuraminda ayartma kavram. Uluslararasi Din \& Felsefe Arastirmalari Dergisi, 1(1), 29-45.

Ozen, H. (2017). Subterranean failures of education in flourishing individuals: from the perspectives of paradigm and the simulation theory. American International Journal of Social Science, 6(2), 25-33.

Rousseau, J. J. (2009). Emile. İstanbul: Kültür Yayınları

Topçu, N. (2015). Türkiyénin maarif davası. İstanbul: Dergah.

Turan, S. (2014). Ahlaki açıdan modern okulun açmazı: Eleştirel bir bakış. Yeni Türkiye Dergisi, 58/59 (10), 246-252.

Spring, J. (2010). Özgür eğitim (Çev. A. Ekmekçi). İstanbul: Ayrunt.

Wink, J. (2004). Critical pedagogy: Notes from real world. New York: Allyn\&Bacon

Versenyi, L. (2007). Sokratik hümanizm. İstanbul: Sentez.

Virilio, P. (1998). Hız ve politika (Çev. M. Cansever). İstanbul: Metis.

Yücel, H. A. (2012). İyi vatandaş iyi insan. İstanbul: İş Bankası Yayınları.

\section{Kaynakça Bilgisi / Citation Information}

Özen, H. (2020). Dromokratik çağda eğitim ve okulun açmazları: Paul Virilioik açıdan analojik bir çözümleme. OPUS-Uluslararası Toplum Araştırmaları Dergisi, 16(Eğitim ve Toplum Özel Sayıs1), 6437-6459. DOI: 10.26466/opus.724349 